\title{
The Expansion of Higher Education and Overeducation in Taiwan: Evidence from 1997 to 2007
}

\author{
Xiao Lin
}

\begin{abstract}
Abstrac-Higher education in Taiwan underwent rapid development over the past two decades. This research adopted the resultsof the survey on the present state of human resources conducted by the Directorate General of Budget, Accounting and Statistics to investigate the influence of overeducation on the human resource market. This study incorporated multiple methods of calculating overeducation to investigate the inconsistencies between the results and the explanations for these. Results showed that the rate of overeducation did not show much variation in the past decade according to both the standard deviation method and the modal method and that the findings conformed to the statistical results of past domestic studies. The salary regression model provided a good explanatory effect of overeducation and undereducation, and was conducive to the explanation and analysis of education level effects on salary. The standard deviation method was comparatively more effective than the modal method in calculating the rate of overeducation. This is related to the looser definition of adequate education in the standard deviation method.
\end{abstract}

Index Terms-Overeducation, undereducation, higher education, adequate education, required education.

\section{INTRODUCTION}

Regarding the development of higher education in Taiwan, the number of university students increased from 470,000 in 1999 to $1,007,000$ in 2008. The gross enrolment ratio of college students reached $83.6 \%$ in 2006 , placing second in the world next to Korea at $91 \%$. The fact is, almost every student is guaranteed a spot in university, and the admission scores required to get into university have reached a record low. Viewing educational investment from the perspective of school admissions, it seems that there now exists a situation where supply exceeds demand.

Additionally, students who graduated from higher education in the past usually did not have to worry about their employment options. In the past, the motivation for receiving higher education lay in the fact that the more education they received, the higher they could expect their salaries to be. However, with the proliferation of higher education came higher rates of unemployment. Since 2007, candidates who graduated from university or higher composed the highest rate of unemployment at $4.5 \%$, which is higher than the overall average of $3.91 \%$, indicating that higher education does not guarantee employment. This situation is the motivation for this study. This study seeks to investigate the connection between salary return rate and education level based on the expansion of higher education and

Manuscript received May 10, 2014; revised August 7, 2014.

Xiao Lin is with the National Chi Nan University, Taiwan (e-mail: xiaolin@ncnu.edu.tw). overeducation to serve as a reference for the development and modification of higher education policies.

\section{RESEARCH THEORIES AND HYPOTHESES}

Higher education is the final stage in the education system. It has always been considered as one of the important indices of educational development, and countries worldwide invest heavily in this sector to promote development. Hung [1] indicated that since 1987, there has been a major development in higher education in Taiwan. This study investigates the problems surrounding the expansion of higher education and overeducation in Taiwan.

\section{A. The Expansion of Higher Education Triggered Concern of Overeducation}

Since the $20^{\text {th }}$ century, the government became involved in educational policies, leading to continued growth and improvements at all levels of education. Following the Second World War, the United States developed higher education to accommodate the needs of the large amount of retired servicemen. Thus, it was also the United States that started the trend of overeducation [2]. By the end of the $20^{\text {th }}$ century, this issue began gaining attention in other parts of the world, and in particular, Europe [3], ,4] and Asia [1], [5] started facing the problem of overeducation. This signifies that these regions caught up with the speed of higher educationexpansion in the United States and thus faced the same problems of overeducation and changes in the labor market.

The speed of higher education expansion in Taiwan was assisted by the lifting of restrictions on the private education, the restructuring and upgrading of schools and expansion of enrollment, as well as the slower trend of population growth. All these led to the ample development of higher education. However, since higher education is intricately connected to employment preparation, the employment situation of graduates has become an important indicator of its success. According to statistics, the unemployment rates of 20- to 24-year-olds and 25- to 29-year-olds who graduated from university or higher were $14.89 \%$ and $7.07 \%$, which were higher than the average unemployment rate of $11.89 \%$ and $6.38 \%$ in their respective age brackets. This suggests that the ability of higher education to accumulate human capital contradicts the original intention of educational investment. Thus, the problem of overeducation arises with the development of higher education, suggesting that these people's jobs do not require such education levels. This study investigated the expansion of higher education and the change in education levels required for different occupations as indicated in employment literature over the past decade (1997-2007) as a foundation for our discussion of 
overeducation.

\section{B. The Causes of Overeducation and the Rate of Return on Educational Investment}

From an educational perspective, if the purpose of receiving higher education is self-realization, there would be no problem of overeducation. However, in terms of the rate of return of investment, education has to compete with other public affairs for resources. Preparing for a good paying job or career through higher education has been the original economic motivation of most students in receiving higher education. When such a motivation is not sufficiently satisfied, the occurrence or feeling of overeducation appears.

The term overeducated is usually applied to young candidates, which is equated to lacking in experience. Many studies show that overeducation is usually a temporary situation, especially for people with high educational achievements. The reason behind this is that: formal education received in school is but a form of accumulating human capital, and work experience and professional training are equally important [6]-[8]. With some modifications in job specifications the problem of overeducation will gradually disappear. According to the Directorate General of Budget, Accounting and Statistics, although 20- to 29-year-olds who graduated from university or higher ranked first in terms of unemployment levels, the average rate of unemployment for 30 - to 34 -year-olds was $3.89 \%$, while those who graduated from university or higher was $3.08 \%$, ranking the lowest in that age category regardless of education level. This suggests that education and experience are complementary.

Regarding the definition of overeducation, it is evident that the education level of new arrivals in the job market is continually rising, and at the same time, the same occupations no longer have vacancies for new graduates [9]. Additionally, it is widely believed that, when comparing the same occupation, the overeducated receives significantly lower salaries when compared with those with adequate education. For those with the same education level, workers who are overeducated receive higher salaries than those with adequate education [10], [11].

\section{The Measurement of Overeducation}

The connection between education level and the abilities required for a job is theoretically expressed through overeducation, adequate education, and undereducation. However, there are several measurement methods available, one type being subjective measurement and the other being objective measurement [12]. The most representative subjective measurement method is the worker self-assessment developed by Duncan and Hoffman [13]. This method allows the study subjects to assess whether they are overeducated or undereducated in terms of the relation between the education level required for their work and their own qualifications; this method is also known as the WA method. Objective measurement methods are usually based on surveys on the present state of human resources and are divided into four types: one is the job analysis method [11], which is otherwise known as the JA method; the education level required for the job is decided based on an analysis of the job specifications. Another type is the modal method; the education level required for the job is decided based on the education level of the majority. The third method is thestandard deviation method; the education level required for the job is decided based on the average number of years of education the workers in this occupation have received, plus or minus one standard deviation. The fourth type is a customized standard deviation method revised by the researcher, known as the semi-standard deviation method, whereby the plus-and-minus range is reduced to half a standard deviation. According to a survey in Taiwan in 2002, the rate of overeducation is $45 \%$ using the WA method and only $13 \%$ using the RM method; the figures conform to findings from studies conducted abroad.

\section{RESEARCH METHODS}

This study used two methods. First, the measurement of overeducation was calculated through the standard deviation method and the modal method; meanwhile, the salary model was conducted using Mincer's regression analysis to obtain the influence of education and other variables on salary. Second, the occurrence rate of overeducation was calculated using logistic regression. The procedures are explained in detail in the following section:

\section{A. Methods for Measuring Overeducation}

Mincer's regression equation is the common choice for evaluating education and salary levels in a human capital model. It is used to investigate the influence of education and professional training on salary levels.

$$
\ln Y_{i}=\ln Y_{0}+\beta_{1} s_{i}+\beta_{2} X_{i}+\beta_{3} X_{i}^{2}+u_{i}
$$

$\beta_{1}$ represents the rate of return of education; si refers to the number of years of education; $\beta_{2}$ refers to the rate of return of professional training; and $X i$ refers to the work experience of the $i^{\text {th }}$ worker, usually obtained through subtracting the number of years of education from the worker's age, minus six years. The squared item indicates the fact that salary increases with experience before decreasing later.

There are five methods of measuring overeducation. Due to the variety, there is a dearth of studies applying the job analysis method (JA). There is no mention of the worker self-assessment method (WA) in the survey on the present state of human resources conducted by the Directorate General of Budget, Accounting and Statistics; the Academia Sinica's "Taiwan Social Change Survey" includes such questions, but is not conducted annually. Since the semi-standard deviation method is used less frequently, this study adopted the modal method and the standard deviation method to simplify the research process. These two methods were used by adding the variable of overeducation to Mincer's method.

The standard deviation method was developed by Verdugo and Verdugo [14], and is otherwise known as the means of realized matches, or the RM method. The regression equation is as follows:

$$
\ln Y=\beta_{0}+\Psi X+\Phi_{o} O V E R E D+\Phi_{u} U N D E R E D+\mu
$$

Here, $\ln Y$ refers to the natural logarithm of salary, OVERED and UNDERED are the virtual variables of overeducation and undereducation, $X$ is the vector of 
education and other explanatory variables (such as marital status, field of occupation, gender, and employment organization), $\Psi$ is the coefficient vector, and $\mu$ is the error term.

The modal method was developed by Duncan and Hoffman (1981). Its regression equation is as follows:

$$
\ln Y=\alpha+Z \beta+\phi_{r} A D S C H+\phi_{o} O V E R S C H+\phi_{u} U N D E R S C H+\varepsilon
$$

Here, $Z$ refers to the remaining independent variable vectors after the variable of education was removed, $\beta$ is the coefficient vector, and $\varepsilon$ is the error term. The total number of years of education received is further classified into several variables: the number of years of adequate education (ADSCH), the number of years of overeducation (OVERSCH), and the number of years of undereducation (UNDERSCH). The ideal coefficient vector in the equation should be $\phi_{r}>0, \phi_{o}>0, \phi_{u}<0, \phi_{r}>\phi_{o}$. The average rate of return of the number of years of education required is $\phi_{r}$; $\phi_{o}$ refers to the rate of return of the required education compared to colleagues with adequate education; and $\phi_{u}$ refersto the rate of return of the undereducation compared to colleagues with adequate education.

\section{B. Measuring the Occurrence Rate of Overeducation and Its Reasons}

According to past research, the rate of overeducation can be related to several individual characteristics. These characteristics and the rate of overeducation can be expressed as:

$\log \left(P_{O} / P_{A}\right)=\beta_{1}+\beta_{2} E D+\beta_{3} E X P+\beta_{4} E X P^{2}+\beta_{5} \mathrm{GEN}+\beta_{6} \mathrm{EMP}+\beta_{6} M A R$

In the equation, ED represents the education level, EXP represents experience, $\mathrm{EXP}^{2}$ represents experience squared, GEN represents gender, EMP represents the employer, and MAR represents marital status. If the coefficient vectors of $\beta_{2}$ to $\beta_{6}$ are lower than 0 , it signifies that the variable reduces the rate of overeducation; alternatively, if the coefficient vectors of $\beta_{2}$ to $\beta_{6}$ are higher than 0 , it signifies that the variable increases the rate of overeducation.

\section{RESULTS}

The results presented the definition of the data and the analysis of the description statistics based on the characteristics of the variables. Additionally, statistics and explanations were developed regarding the influence of the rate of overeducation, education level (including overeducation and undereducation), and other variables on salary levels, as well as the variables that influence the occurrence rate of overeducation.

\section{A. Using Variables}

Table I shows the variables used in the salary regression model. lnwage is the natural logarithm of hourly wage and sch refers to the number of years of formal education received. Experience refers to the number of years after graduation, i.e., age subtracted by the number of years of schooling and the number of years before schooling.
Additionally, the square of experience indicates that the variables have a quadratic (and not linear) influence towards salary levels. Regarding the population variable mar, in addition to single $=1$, others $=0$, there were also those who were divorced or widowed in the sample. However, the latter two consisted of a mere $5 \%$ of the entire sample and were not the foci of this study and were thus classified under married. gen, male $=1$, others $=0$. emp, public $=1$, other $=0$; here, other possible choices such as owners, self-employed, and nonprofit are not considered and only include employees that are employed by private units. The two virtual variables of ovedu and unedu were used in the standard deviation method, while the three quantity variables of adsch, ovsch, and unsch were applied in the modal method.

TABLE I: DESCRIPTIVE STATISTICS, MANPOWER SURVEY STATISTICS, 1997-2007

\begin{tabular}{l|r|r|r}
\hline & Mean & SD & Note \\
\hline Year & \multicolumn{3}{|c}{$2007(N=20784)$} \\
\hline lnwage & 5.20 & .44 & \\
\hline sch & 12.68 & 3.13 & \\
\hline ex & 18.53 & 11.85 & \\
\hline mar & .4 & .489 & \\
\hline gen & .57 & .50 & \\
\hline emp & .14 & .35 & \\
\hline ovedu & .12 & .33 & \\
\hline unedu & .18 & .38 & \\
\hline adsch & 13.35 & 2.01 & $\begin{array}{r} \\
\text { ovsch }\end{array}$ \\
\hline unsch & 3.84 & 1.22 & $N=4189$, overeducation \\
\hline
\end{tabular}

\section{B. Variation in Education Level in Different Occupations} from 1997 to 2007

TABLE II: AVERAGE YEARS OF SCHOOLING OF OCCUPATIONS AND THE

\begin{tabular}{|c|c|c|c|c|}
\hline \multirow[t]{2}{*}{ Occupation } & \multicolumn{2}{|c|}{$\begin{array}{c}\text { Average Years } \\
\text { of Schooling }\end{array}$} & \multicolumn{2}{|c|}{ Mode class } \\
\hline & 1997 & 2007 & 1997 & 2007 \\
\hline $\begin{array}{l}\text { Legislators, Gov. } \\
\text { Administrators, } \\
\text { Business Executives \& } \\
\text { Managers }\end{array}$ & 13.59 & 14.71 & $\begin{array}{l}\text { University } \\
(29.6)^{*}\end{array}$ & $\begin{array}{l}\text { University } \\
(32.8)\end{array}$ \\
\hline Professionals & 15.35 & 16.18 & $\begin{array}{c}\text { University } \\
(46.3)\end{array}$ & $\begin{array}{c}\text { University } \\
(53.7)\end{array}$ \\
\hline $\begin{array}{l}\text { Technicians and } \\
\text { Associate Professionals }\end{array}$ & 13.28 & 14.35 & $\begin{array}{c}\text { Senior High } \\
\text { School }(40.1) \\
\end{array}$ & $\begin{array}{c}\text { University } \\
(37.8)\end{array}$ \\
\hline Clerks & 12.58 & 13.59 & $\begin{array}{l}\text { Senior High } \\
\text { School }(56.1)\end{array}$ & $\begin{array}{c}\text { Senior High } \\
\text { School } \\
(38.8) \\
\end{array}$ \\
\hline $\begin{array}{l}\text { Service Workers and } \\
\text { Shop and Market Sales } \\
\text { Workers }\end{array}$ & 10.64 & 11.79 & $\begin{array}{l}\text { Senior High } \\
\text { School (47.3) }\end{array}$ & $\begin{array}{c}\text { Senior High } \\
\text { School } \\
(50.4) \\
\end{array}$ \\
\hline $\begin{array}{l}\text { Agricultural, Animal } \\
\text { Husbandry, Forestry } \\
\text { and Fishing Workers }\end{array}$ & 6.84 & 8.56 & $\begin{array}{c}\text { Elementary } \\
\text { School }(50.0)\end{array}$ & $\begin{array}{c}\text { Elementary } \\
\text { School } \\
(38.4) \\
\end{array}$ \\
\hline $\begin{array}{l}\text { Prod., Machine } \\
\text { Operators and Related } \\
\text { Workers }\end{array}$ & 9.20 & 10.53 & $\begin{array}{l}\text { Senior High } \\
\text { School (32.6) }\end{array}$ & $\begin{array}{c}\text { Senior High } \\
\text { School } \\
(45.4)\end{array}$ \\
\hline
\end{tabular}

Note: percentage in parentheses.

It is evident from Table II that the average number of years of education received by workers in various occupations have increased significantly, signaling that the expansion of higher education achieved the purpose of boosting the education level of the employed population in all areas. The results of the modal method showed that the education level for adequate education has either remained or increased 
throughout the years. The most significant change occurred with Technicians and Associate Professionals, whose education level rose from vocational school to university level.

In many studies on overeducation, researchers focused on the percentage of overeducation against adequate education. In Table III, except for Technicians and Associate Professionals, the rate of overeducation for the remaining occupations has increased significantly, indicating the overall rise in general education caused by the expansion of higher education. However, there exists the logical problem of designating the appropriate level of education. In the category of Technicians and Associate Professionals, the number of overeducated workers fell from $53.1 \%$ in 1997 to $6.2 \%$ in 2007 . Do such figures prove that the number of overeducated workers have significantly decreased in the said professions? In truth, the real reason lies in what was mentioned in the previous section, that the change in figures was caused by the significant increase in workers with adequate education. Thus, the overall overeducation levels in this category fell $0.3 \%$ when compared with the figures in 1997 , which is completely opposite to the other professions.

TABLE III: THE PERCENTAGE OF ADEQUATE AND OVEREDUCATION SCHOOLING IN MODAL METHOD

\begin{tabular}{|c|c|c|c|c|}
\hline \multirow[t]{2}{*}{ Occupation } & \multicolumn{2}{|c|}{$\begin{array}{l}\text { Adequate } \\
\text { Schooling }\end{array}$} & \multicolumn{2}{|c|}{$\begin{array}{l}\text { Overeducation } \\
\text { Schooling }\end{array}$} \\
\hline & 1997 & 2007 & 1997 & 2007 \\
\hline $\begin{array}{l}\text { Legislators, Gov. } \\
\text { Administrators, Business } \\
\text { Executives \& Managers }\end{array}$ & 29.6 & 32.8 & 7.0 & 19.2 \\
\hline Professionals & 46.3 & 53.7 & 13.5 & 24.8 \\
\hline $\begin{array}{l}\text { Technicians and Associate } \\
\text { Professionals }\end{array}$ & 40.1 & 37.8 & 53.1 & 6.2 \\
\hline Clerks & 56.1 & 38.8 & 35.3 & 56.6 \\
\hline $\begin{array}{l}\text { Service Workers and Shop and } \\
\text { Market Sales Workers }\end{array}$ & 47.3 & 50.4 & 15.3 & 25.6 \\
\hline $\begin{array}{l}\text { Agricultural, Animal } \\
\text { Husbandry, Forestry and } \\
\text { Fishing Workers } \\
\end{array}$ & 50.0 & 38.4 & 35.8 & 58.4 \\
\hline \multirow[t]{2}{*}{$\begin{array}{l}\text { Prod., Machine } \\
\text { Operators and Related } \\
\text { Workers }\end{array}$} & 32.6 & 45.4 & 5.4 & 11.4 \\
\hline & & & 20.5 & 20.2 \\
\hline
\end{tabular}

It was previously mentioned in the literature review section that the rate of overeducation is influenced by the type of measurement used. The average overeducation rates were at their lowest with the use of the standard deviation method. After analyzing 25 studies on overeducation, Groot and Maassen van den Brink [12] found that the average value obtained through the standard deviation method was $13.1 \%$. Table IV shows that the figures for Taiwan were $10.9 \%$ and $12.1 \%$ for 1997 and 2007 respectively, which were similar to those obtained in studies elsewhere. However, the rate of overeducation for Professionals, Technicians and Associate Professionals, Service Workers and Shop and Market Sales Workers dropped sharply in 2007 when compared with 1997 , which differs from the overall impression that there is a trend of overeducation in all kinds of professions in society. This was probably caused by the loose definition of adequate education in the Standards Act, leading to a lack of sensitivity towards occurrences of overeducation.
TABLE IV: THE PERCENTAGE OF ADEQUATE EDUCATION AND OVEREDUCATION IN STANDARD DEVIATION METHOD

\begin{tabular}{|c|c|c|c|c|}
\hline \multirow[t]{2}{*}{ Occupation } & \multicolumn{2}{|c|}{ adequate education } & \multicolumn{2}{|c|}{ overeducation } \\
\hline & 1997 & 2007 & 1997 & 2007 \\
\hline $\begin{array}{l}\text { Legislators, Gov. } \\
\text { Administrators, Business } \\
\text { Executives \& Managers }\end{array}$ & 80.3 & 32.8 & 7.0 & 19.2 \\
\hline Professionals & 75.7 & 53.7 & 13.5 & 4.7 \\
\hline $\begin{array}{l}\text { Technicians and Associate } \\
\text { Professionals }\end{array}$ & 71.9 & 37.8 & 21.3 & 6.2 \\
\hline Clerks & 81.2 & 38.8 & 10.2 & 29.8 \\
\hline $\begin{array}{l}\text { Service Workers and Shop } \\
\text { and Market Sales Workers }\end{array}$ & 67.9 & 50.4 & 15.3 & 8.5 \\
\hline $\begin{array}{l}\text { Agricultural, Animal } \\
\text { Husbandry, Forestry and } \\
\text { Fishing Workers }\end{array}$ & 70.2 & 38.4 & 15.6 & 29.2 \\
\hline $\begin{array}{l}\text { Prod., Machine } \\
\text { Operators and Related } \\
\text { Workers }\end{array}$ & 64.2 & 45.4 & 5.4 & 11.4 \\
\hline All & & & 10.9 & 12.1 \\
\hline
\end{tabular}

\section{Overeducation and the Rate of Return for Education Investment}

TABLE V: EARNINGS REgRESSIONS: STANDARD DEVIATION METHOD AND MODAL METHOD

\begin{tabular}{|c|c|c|c|c|c|c|c|c|}
\hline & \multicolumn{4}{|c|}{$\begin{array}{l}\text { standard deviation } \\
\text { method }\end{array}$} & \multicolumn{4}{|c|}{ modal method } \\
\hline & \multicolumn{2}{|c|}{1997} & \multicolumn{2}{|c|}{2007} & \multicolumn{2}{|c|}{1997} & \multicolumn{2}{|c|}{2007} \\
\hline & $\mathrm{B}$ & $\beta$ & $\mathrm{B}$ & $\beta$ & $\mathrm{B}$ & $\beta$ & $\mathrm{B}$ & $\beta$ \\
\hline $\begin{array}{c}\text { consta } \\
\text { nt }\end{array}$ & $\begin{array}{l}3.6 \\
80\end{array}$ & & $\begin{array}{l}3.5 \\
55\end{array}$ & & $\begin{array}{c}3.26 \\
2\end{array}$ & & $\begin{array}{c}3.26 \\
3 \\
\end{array}$ & \\
\hline sch & $\begin{array}{c}.07 \\
5\end{array}$ & .553 & $\begin{array}{c}.09 \\
4\end{array}$ & $\begin{array}{c}.66 \\
8\end{array}$ & & & & \\
\hline ovedu & $\begin{array}{c}-.02 \\
8\end{array}$ & $\begin{array}{c}-.01 \\
9\end{array}$ & $\begin{array}{l}-.1 \\
05\end{array}$ & $\begin{array}{l}-.0 \\
78\end{array}$ & & & & \\
\hline unedu & $\begin{array}{c}.16 \\
0\end{array}$ & .137 & $\begin{array}{c}.16 \\
0\end{array}$ & $\begin{array}{c}.14 \\
0\end{array}$ & & & & \\
\hline adsch & & & & & .106 & .334 & .114 & .533 \\
\hline ovsch & & & & & .089 & .236 & .078 & .225 \\
\hline unsch & & & & & -.036 & -.199 & -.045 & -.203 \\
\hline ex & $\begin{array}{c}.03 \\
0\end{array}$ & .780 & $\begin{array}{l}.02 \\
4\end{array}$ & $\begin{array}{c}.65 \\
4\end{array}$ & .029 & .782 & .024 & .651 \\
\hline$e x^{2}$ & $\begin{array}{c}-.00 \\
04\end{array}$ & $\begin{array}{c}-.53 \\
5\end{array}$ & $\begin{array}{c}-.0 \\
00 \\
3\end{array}$ & $\begin{array}{l}-.3 \\
58\end{array}$ & $\begin{array}{c}-.000 \\
4\end{array}$ & -.562 & $\begin{array}{c}-.000 \\
3\end{array}$ & -.396 \\
\hline gen & $\begin{array}{c}.30 \\
9\end{array}$ & .327 & $\begin{array}{c}.23 \\
0\end{array}$ & $\begin{array}{c}.26 \\
0\end{array}$ & .307 & .326 & .217 & .245 \\
\hline mar & $\begin{array}{c}-.04 \\
4\end{array}$ & $\begin{array}{c}-.04 \\
6\end{array}$ & $\begin{array}{l}-.0 \\
65\end{array}$ & $\begin{array}{l}-.0 \\
73\end{array}$ & -.041 & -.042 & -.062 & -.069 \\
\hline emp & $\begin{array}{c}.16 \\
0\end{array}$ & .128 & $\begin{array}{c}.22 \\
2\end{array}$ & $\begin{array}{c}.17 \\
5\end{array}$ & .151 & .121 & .227 & .180 \\
\hline $\mathrm{n}$ & \multicolumn{2}{|c|}{21547} & \multicolumn{2}{|c|}{20784} & \multicolumn{2}{|c|}{21547} & \multicolumn{2}{|c|}{20784} \\
\hline $\operatorname{adj.} R^{2}$ & \multicolumn{2}{|c|}{.403} & \multicolumn{2}{|c|}{.464} & \multicolumn{2}{|c|}{.427} & \multicolumn{2}{|c|}{.494} \\
\hline
\end{tabular}

Note: All coefficients are significant at. $1 \%$.

All of the regression coefficient vectors in Table $\mathrm{V}$ reached the .001 level of significance, indicating that the variables used were all factors that explain the changes in salary levels. However, this is of course intimately related to the size of the sampling population. The relationship between independent variables and salary levels remained constant throughout the decade. The explanation value (the adjusted R-squared values) of all the variables rose from .403 in 1997 to .464 in 2007 as indicated by the standard deviation method, while the figure derived through the modal method rose from .427 in 1997 to .494 in 2007 , indicating that these variables were better suited to explaining the changes in salary levels compared to those in 1997.

The characteristics of variables used in the standard 
deviation method and the modal method regarding overeducation and undereducation are different, with the former employing virtual variables, and the latter quantity variables; thus, the explanation values of the former are usually smaller than the latter. Additionally, adsch, ovsch, and unsch conform to the prediction values of $\phi_{r}>0$ $(.106, .114), \phi_{o}>0(.089, .078), \phi_{u}<0 \quad(-.036,-.045)$, $\phi_{r}>\phi_{o}(.106>.089, .114>.078)$ throughout the years.

\section{Influence Variables Relevant to Overeducation (Logistic Regression Analysis)}

Table VI presents the logistic regressionanalysis of overeducation. All the independent variables reached the .01 to .001 level of significance on the dependent variables (the ratio of overeducation against adequate education) through the standard deviation method. Education level (sch), marital status (mar), and gender (gen) were positively correlated, indicating the relative rise in education level and unmarried and male workers; the rate of overeducation also rose accordingly. Experience (ex) and employer (emp) were negatively correlated, indicating the relative rise in experience and employment in public offices; the rate of overeducation also fell accordingly.

TABLE VI: THE LOGIT MODEL OF OVEREDUCATION

\begin{tabular}{l|c|c|c|c}
\hline & \multicolumn{5}{|c}{ standard deviation method } & \multicolumn{2}{c}{ modal method } \\
\hline & $\mathrm{B}$ & $\exp (\mathrm{B})$ & $\mathrm{B}$ & $\exp (\mathrm{B})$ \\
\hline sch & $.636 * *$ & 1.888 & $.504 * * *$ & 1.655 \\
\hline tenu & $-.029 * * *$ & .971 & $-.015 * * *$ & .986 \\
\hline $\mathrm{exp}$ & $-.023 * * *$ & .977 & $-.014 * * *$ & .986 \\
\hline gen & $.149 * *$ & 1.161 & -.070 & .933 \\
\hline mar & $.302 * * *$ & 1.352 & $.209 * * *$ & 1.232 \\
\hline emp & $-.688^{* * *}$ & .502 & -.071 & .932 \\
\hline constant & $-10.837 * * *$ & .000 & $-7.922 * * *$ & .000 \\
\hline $\begin{array}{l}\text { Nagelkerke } \\
R^{2}\end{array}$ & .361 & & .295 \\
\hline $\begin{array}{l}\text { Log } \\
\text { Likelihood }\end{array}$ & -5178.70 & & -6713.18 \\
\hline $\begin{array}{l}\text { percentage } \\
\text { correctly } \\
\text { classified } \\
\text { (hit ratio) }\end{array}$ \\
$\begin{array}{l}* * * \text { Significant at.1\% } \\
* * \text { Significant at } 1 \% \\
* \text { Significant at } 5 \%\end{array}$
\end{tabular}

The modal method. Education level (sch), marital status (mar)were positively correlated and reached the .001 level of significance, indicating the relative rise in education level and unmarried workers; the rate of overeducation also rose accordingly. Experience (ex) was negatively correlated, indicating the relative rise in experience; the rate of overeducation also fell accordingly. The results for the variables of gender (gen) and employer (emp) were different with those obtained through standard deviation; however, it did not reach the .05 level of significance and was thus not included in the discussion.

Overall, the logistic regression analysis results of overeducation obtained through the standard deviation method were comparatively more significant that those obtained through the modal method. In the standard deviation method, the ratio of adequate education was higher, the occurrence rate of overeducation was lower, and the data was more similar to the 1997 results.

\section{Conclusion And Suggestions}

\section{A. Conclusion}

In the realm of overeducation, the rise in education levels also led to the rise in adequate education levels in all professions. Thus, there had not been a significant rise in overall overeducation levels in the past decade (there was an increase of $1.2 \%$ in the standard deviation method and a decrease of $0.3 \%$ in the modal method). This indicates that the phenomenon of overeducation cannot be used as a significant index in both the standard deviation method and the modal method. There are two possible reasons for such results: one is that the expansion of education does not always lead to overeducation, and overeducation may not have occured or it may not be very significant; another is that these two methods may not be able to reflect the phenomenon of overeducation in statistical and logical terms, and require the use of other supplementary evaluation methods (such as the job analysis method (JA method) or the worker self-assessment method).

In the salary regression model, the addition of both overeducation and undereducation variables was more appropriate that just the inclusion of the sole variable of education level. This indicates that although education level can be used to predict income levels, the relationship between education and salary levels should not be seen as linear, but instead should be evaluated for its excessiveness or inadequacy and separately assessed to improve the reasonableness and accuracy of the explanation.

Regarding the variables that increase the occurrence rate of overeducation, results showed that education level and unmarried status significantly boost the rate of overeducation, while experience significantly decreases the rate of overeducation. Additionally, the male gender increases the rate of overeducation in the standard deviation method, while employment organization decreases the rate of overeducation in the same method. However, these variables did not reach the significance level in the modal method and should be further analyzed.

\section{B. Suggestions}

Based on assessments through the standard deviation method and the modal method, there were no significant differences between the overeducation situation between 1997 and 2007. The analysis of the shifts in overeducation trends might be more appropriate using the worker self-assessment analysis (WA) method or the job analysis (JA) method than the statistics-based methods of standard deviation and modal methods. Although the WA method overestimates the problem of overeducation, there is a significant difference between its data collection and assessment methods, which is precisely the value of this method.

In the salary regression model, the addition of the overeducation and adequate education variables significantly increased the explanation rate of the entire equation. These additional variables were all based on education level and not variables that are unrelated to education and are thus conducive to educational research. It is worth noting that in the past, research on education and salary issues did not emphasize the overeducation variable, leading to low explanation values and lack of attention to education in the 
salary equation. Future studies should focus on how to more accurately assess the influence of overeducation and undereducation toward salary levels.

With regards to the occurrence rate of overeducation, the standard deviation method has more significant influence variables than the modal method, as well as presenting a more accurate model as a whole. This is related to the fact that adequate education is more loosely defined in the standard deviation method, leading to more significant occurrences in overeducation and undereducation. Future studies should incorporate more assessment methods to improve the reliability and validity of each model.

\section{REFERENCE}

[1] C. Hung, "Overeducation and undereducation in Taiwan," Journal of Asian Economics, vol. 19, no. 2, pp. 125-137, April 2008

[2] R. Freeman, The Overeducated American, NY: Academic Press, 1976.

[3] K. Tomas and T. Michael, "Educational mismatch, wages, and wage growth: Overeducation in Sweden, 1974-2000," Labour Economics, vol. 16, pp. 183-193, April 2009.

[4] J. P. Guironnet and N. Peypoch, "Human capital allocation and overeducation: A measure of French productivity (1987, 1999)," Economic Modeling, vol. 24, no. 3, pp. 398-410, May 2007.

[5] F. Li, W. J. Morgan, and X. Ding, "The expansion of higher education, employment and over-education in China," International Journal of Educational Development, vol. 28, no. 6, pp. 687-697, Nov. 2008.

[6] P. J. Sloane, H. Battu, and P. T. Seaman, "Overeducation and the formal education/experience and training trade-off," Applied Economics Letters, vol. 3, no. 8, pp. 511-515, 1996.

[7] S. Rubb. "Overeducation: A short or long run phenomenon for individuals?" Economics of Education Review, vol. 22, no. 4, pp. 389-394, Aug. 2003.
[8] M. van Smoorenburg and R. van der Velden, "The training of school-leavers: Complementarity or substitution?" Economics of Education Review, vol. 19, no. 2, pp. 207-217, April 2000.

[9] P. J. Dolton and M. A. Silles, "The effects of over-education on earnings in the graduate labour market," Economics of Education Review, vol. 27, pp. 125-139, April 2008.

[10] A. Alba-Ramirez, "Mismatch in the Spanish labor market: Overeducation?" Journal of Human Resources, vol. 26, pp. 259-278, 1993.

[11] J. Hartog, "Over-education and earnings: where are we, where should we go?" Economics of Education Review, vol. 19, pp. 131-147, April 2000.

[12] W. Groot and H. Maassen van den Brink, "Overeducation in the labor market: A meta-analysis," Economics of Education Review, vol. 19, no. 2, pp. 149-158, April 2000

[13] G. J. Duncan and S. Hoffman, "The incidence and wage effects of overeducation," Economics of Education Review, vol. 1, pp. 75-86, winter 1981.

[14] R. Verdugo and N. Verdugo, "The impact of surplus schooling on earnings: Some additional findings," Journal of Human Resources, vol. 24, pp. 629-643, 1989.

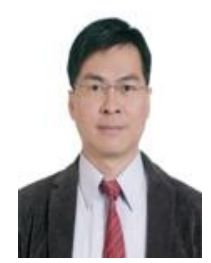

Xiao Lin was born in Taiwan, on June 24, 1969. Xiao earned his doctorate in educational administration from National Chengchi University in Taipei, Taiwan in 2002.

After graduation, he serves in the elementary school and junior college. He is an assistant professor in the National Chi Nan University now. "The higher education tuition and student loans" is published in Journal of Taiwna Education Review, vol. 3, no. 5, pp. 42-47, 2014. His current research topic is about student loan and repayment burden.

Dr. Xiao Lin is a member of the Association of China and Taiwan Higher Education. He is also the reviewer of Forum of Taiwan Education Policy. 